\title{
Energy retrofitting of a single-family house
}

\author{
Imrich Sánka ${ }^{1, *}$ and Dušan Petráš ${ }^{1}$ \\ ${ }^{1}$ Slovak University of Technology in Bratislava, Radlinksého 11, 81005 Bratislava
}

\begin{abstract}
This article shows a real ongoing project called RenoActive, which is financed by company Velux. In cooperation with the company mentioned above an old single-family house was chosen to renovate. Three energy alternatives had been calculated: Standard, Comfort and Deluxe.
\end{abstract}

The thermal insulation system of the building is almost the same in all three alternatives. The alternatives mostly appear in the building services systems.

This article evaluates the energy consumption and investment differences between the alternatives.

\section{Intorduction}

Buildings are responsible for a substantial portion of global energy consumption. Most of the residential buildings in Slovakia that were built in the 20th century do not satisfy the current requirements for energy efficiency presented in the national building code. [1] Nationwide remedial measures have been taken to improve the energy efficiency of these buildings and reduce their energy use [2].

The objectives of this study are:

- Theoretical analyses of the impact of standardising energy saving measures on the IEQ

- Experimental measurements of indoor environmental quality (thermal environment, indoor air quality) in the family house after completing the renovation,

- Experimental evaluation of energy consumption in the family house after renovation,

- To analyse, evaluate and compare the results from the subjective questionnaire survey if they will be statistically significant,

- Monitoring of occupants' energy savings and ventilation habits.

Be aware that this research is at the beginning and additional information will be available in the near future.

Nowadays the renovated houses must complete so called A1 primary energy class rule, according to the law No. 364/2012, 555/2005 and the Decree of the Ministry of Transport, Construction and Regional Development No: $300 / 2012$. It means that the primary energy consumption has to be lower than $108 \mathrm{kWh} /(\mathrm{m} 2 . \mathrm{a})$. The buildings completing this criteria are called as ultra-low energy buildings.

From the year 2021, all the newly built buildings will have to comply the most stricter building energy criteria so far in Slovakia. It means that the houses will have to fit into energy class A0 according to the global indicator. Simplistically the primary energy consumption of the buildings mentioned above need to be lower than 54 $\mathrm{kWh} /(\mathrm{m} 2 . \mathrm{a})$ regarding to family houses, $32 \mathrm{kWh} /(\mathrm{m} 2 . \mathrm{a})$ regarding to apartment buildings and $60 \mathrm{kWh} /(\mathrm{m} 2 . \mathrm{a})$ regarding to office buildings. provides These buildings are called as nearly zero energy buildings (nZEB).

These requirements can be achieved by perfect application and increased thickness of thermal insulation systems on to building envelope. These measures will minimize the heat losses of the building. Except the thermal protection of the building there must be used some kind of renewable energy for hear source (heat pump, gas boiler in combination with photovoltaic panels and solar panels, mechanical ventilation system with heat recovery etc.)

The energy consumption of building sector is directly related to $\mathrm{CO}_{2}$ emissions; account for around $36 \%$ of total emissions in Europe. Moreover, $\mathrm{CO}_{2}$ emissions are directly connected to the particular energy mix used in existing buildings in a particular EU country

This study presents the results of energy balance calculations for each variants of the changing HVAC and thermal protection of the building. Energy in European buildings is mainly consumed by space heating, cooling, hot water preparation, cooking and equipment, where the biggest consumer is space heating.

\footnotetext{
* Corresponding author: imrich.sanka@gmail.com
} 


\section{Building description}

The investigated single-family house (Figure 1.) is located in Šala, Slovakia. It was built between years 1966 and 1970. Its dimensions are: length 11,1m; width 9,0m; max. height $8,2 \mathrm{~m}$.

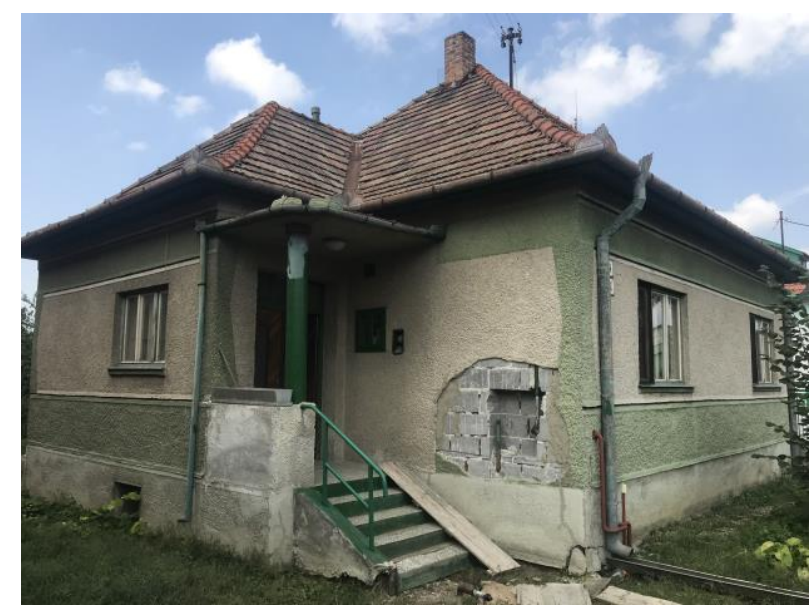

Fig. 1. The evaluated single-family house before renovation

The base point of the work was to find the original documentations (floor plans and cross sections) to the house (Figure 2.). Using this we could do a detailed inspection of the building with its surveying.
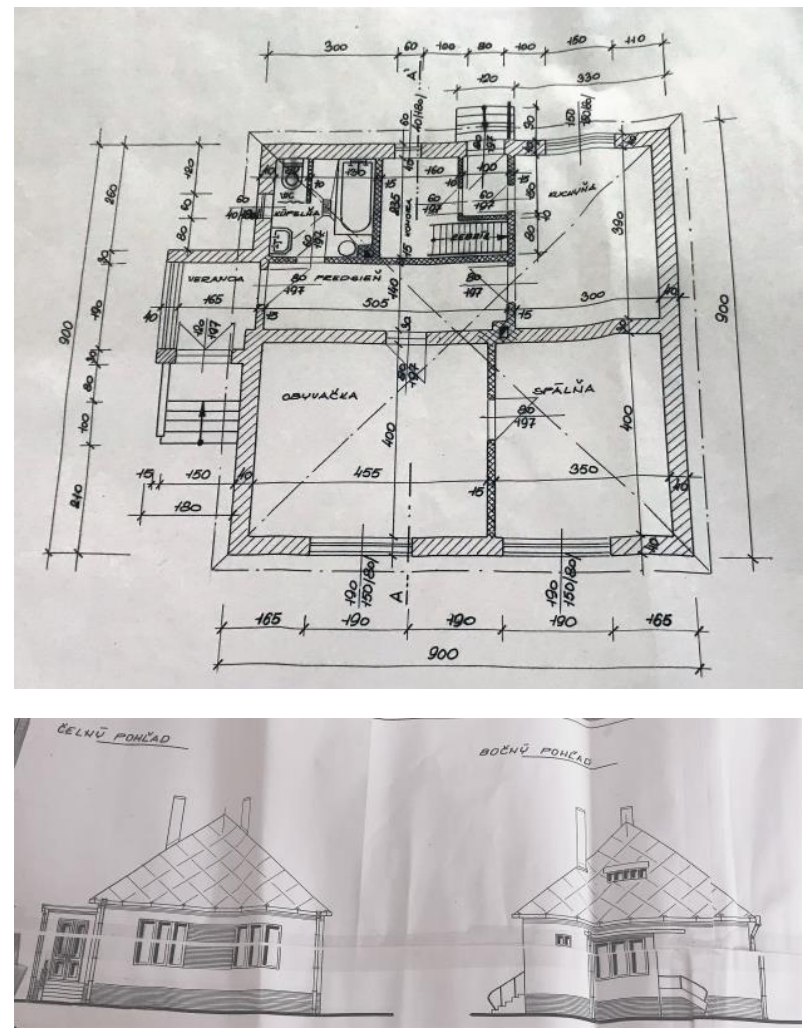

Fig. 2. "Floor plan" (higher) and "front and side view" (lower) from the original project documentation

An architectural study has been created and then based on this study a new project documentation for the reconstruction had been prepared (Figure 3.)
In the new project the designers (Architects Dorsic and Dorsicová) took note of de requirements of a modern family and perfect interior and exterior look.

In the refurbishment the newest technology and materials will be used (as it is stated in the capitol 3.)

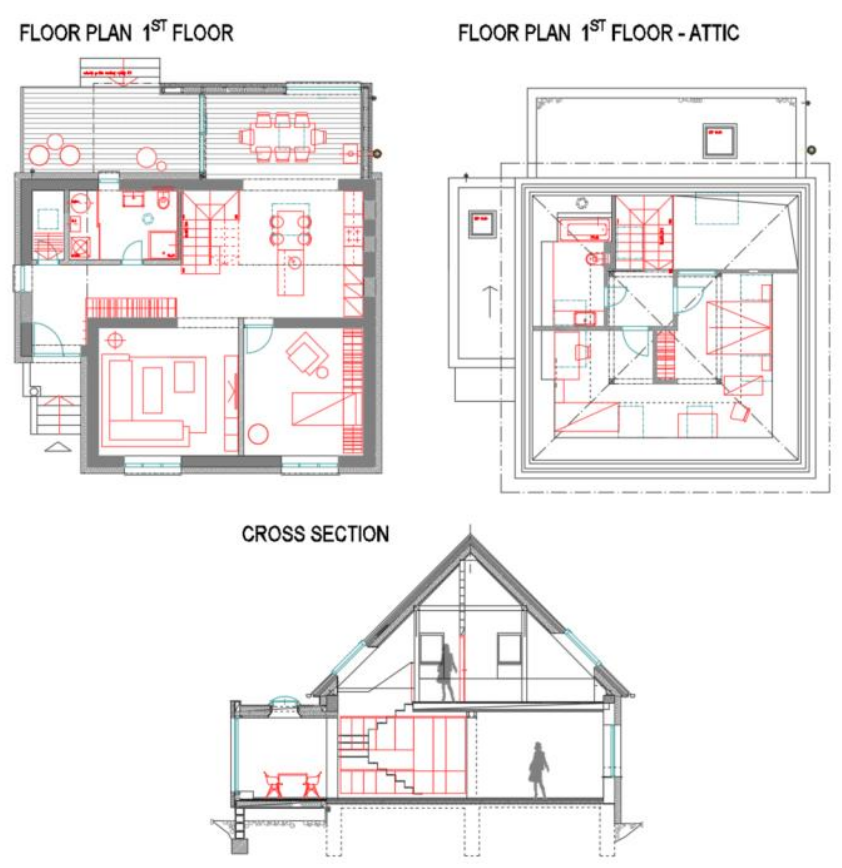

Fig. 3. Project documentation for the building reconstruction. Floor plans of the 2 stories (higher) and a cross section (lower), designed by Mr. and Mrs. Dorsic.

\section{Methodology}

As it was stated in mentioned above the first task after getting of the plans is to define the variants. These variants are based on the boundary conditions of the Slovak standard $730540-Z 1$, where the valid heat transfer coefficients are listed (Table 1.)

Table 1: Heat transfer coefficient STN 730540-/Z1

\begin{tabular}{|c|c|c|}
\hline \multirow{2}{*}{ Building structure type } & \multicolumn{2}{|c|}{$\begin{array}{c}\text { Heat transfer coefficient } \\
\mathrm{W} /(\mathrm{m} 2 . \mathrm{K})\end{array}$} \\
\cline { 2 - 3 } & $\begin{array}{c}\text { Recomm. } \\
\text { value } \\
\text { valid from } \\
2016\end{array}$ & $\begin{array}{c}\text { Target value } \\
\text { valid from } \\
2021\end{array}$ \\
\hline External wall & 0,22 & 0,15 \\
\hline Roof & 0,15 & 0,10 \\
\hline Ceiling above exterior area & 0,15 & 0,10 \\
\hline Ceiling above unheated area & 0,20 & 0,15 \\
\hline Transparent structures / windows \& \\
doors & 1,00 & 0,60 \\
\hline
\end{tabular}


Input data:

Building name: Single-family house

Town: Šala

Parcel No .: $\quad 325$

Total floor area: $204,8 \mathrm{~m} 2$

Interior parameters:

Internal temperature $20^{\circ} \mathrm{C}$

Exterior parameters

Relative humidity $\quad 50 \%$

External temperature $-11^{\circ} \mathrm{C}$

Relative humidity $\quad 83 \%$

Three variants had been elaborated, Standard, Comfort and De-Luxe. Detailed information about them are listed below.

\subsection{Standard}

Recommended values of heat transfer coefficients (valid from 2016) and triple glazed windows, transparent structures with plastic frames will be used to calculate this variant. Terrain floor without modification. External walls will be insulated with $160 \mathrm{~mm}$ thick thermal insulation (mineral wool). The roof will be covered from interior side with drywall system, and thermal insulation will be installed in total thickness of $320 \mathrm{~mm}$ (mineral wool for the tent roof and EPS polystyrene for the flat roofs)

As heat source a condensing gas boiler will be used with floor heating. The regulation will be controlled via internal thermostat and three-way mixing valve in the boiler. The hot water preparation will be provided by the same gas boiler in an external storage tank in total volume of $120 \mathrm{~L}$.

This variant does not calculate with mechanical ventilation system. The air exchange rate will be secured simply with natural ventilation.

\subsection{Comfort}

In this variant the target het transfer coefficient values were be used (except transparent structures). It means Triple glazed windows and doors with aluminium frames. External walls wit thermal insulation with total thickness of 220-240 mm (mineral wool). The roof will be insulated with mineral wool and EPS panels in total thickness of $400 \mathrm{~mm}$. This creates very low het losses by the calculated heat transfer coefficient $0,09 \mathrm{~W} /(\mathrm{m} 2 . \mathrm{K})$. The floor will be insulated as well with mineral wool panels, which are $120 \mathrm{~mm}$ thick.

The heat source will be the same condensing boiler as in the standard variant with floor heating, but the regulation will be equithermic. It means the heat source performance will be changing based on the outside air temperature. The DHW systems primary source will be the same boiler as well, but thermal solar collectors will be used to preheat the water in the DHW system in winter season and to heat the whole volume of the water in the summer season. Therefore here we can not use the 120 L storage tank, because that a $300 \mathrm{~L}$ tank was designed which fulfils the requirements for the solar system as well.

The ventilation would be natural as well, but to the bathrooms and kitchen an air outlet unit will be installed.

\subsection{De-Luxe}

In this variant the same structures will be used as in the variant no. 2 - Comfort, except the transparent constructions. To the calculations were put data form of the four glazed windows with aluminium frames. This structure has extremely low $\mathrm{U}$ value (compared to other types of windows) only $0,55 \mathrm{~W} /(\mathrm{m} 2 . \mathrm{K})$

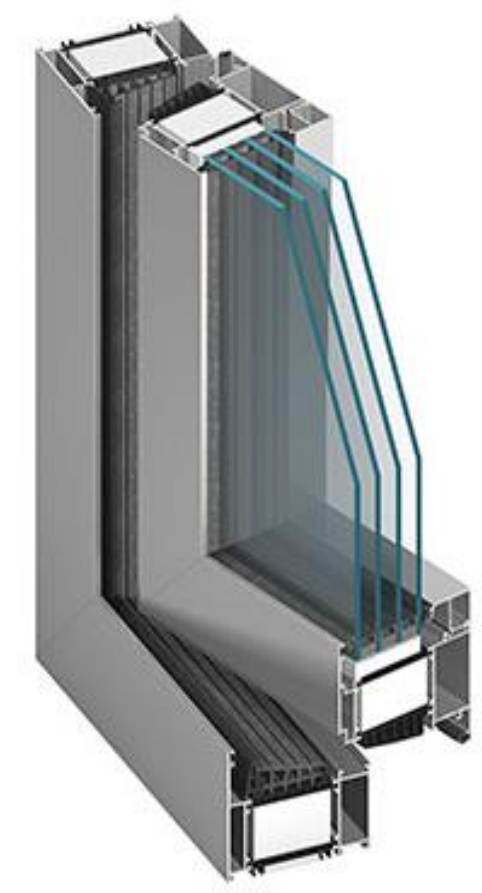

Fig. 4. Aluminium window frame with four glazings - Arcus international

The heat source will be an air source heat pump with 5,5 $\mathrm{kW}$ performance. To support its operation and reduce the lighting cost photovoltaic panels will be used with annual performance of 4,7 MWh. The heating system, regulation and DHW system will be the same as in the previous variant - Comfort.

The ventilation will be mechanical with heat recovery system (minimal efficiency $75 \%$ ). 


\section{Results}

The calculation of energy balance is presented for each of the variants in the following tables.

Table 2: Assessing the properties of structures to their heat transfer coefficient based on STN 730540-2/Z1 Variant Standard

\begin{tabular}{|c|c|c|c|c|}
\hline \multirow{6}{*}{ 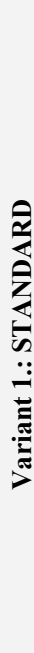 } & \multirow{2}{*}{ Structure type } & \multicolumn{2}{|c|}{$\begin{array}{c}\text { The values of the heat } \\
\text { transfer coefficients } \\
\mathbf{U W} /\left(\mathbf{m}^{2} . \mathrm{K}\right)\end{array}$} & \multirow{2}{*}{$\begin{array}{c}\text { Results } \\
\text { according to } \\
\text { the Standard } \\
730540-2 / Z 1\end{array}$} \\
\hline & & $\begin{array}{l}\text { Designed } \\
\text { value }\end{array}$ & $\begin{array}{c}\text { Recommended } \mathbf{U} \\
\text { value }\end{array}$ & \\
\hline & $\begin{array}{l}\text { External wall1 } \\
\text { External wall } 2\end{array}$ & $\begin{array}{l}0,20 \\
0,14\end{array}$ & 0,22 & $\begin{array}{l}\text { Fulfils the } \\
\text { requirements }\end{array}$ \\
\hline & $\begin{array}{c}\text { Transparent } \\
\text { structures }\end{array}$ & 0,85 & 1,00 & $\begin{array}{l}\text { Fulfils the } \\
\text { requirements }\end{array}$ \\
\hline & $\begin{array}{l}\text { Tent roof } \\
\text { Flat roof }\end{array}$ & $\begin{array}{l}0,12 \\
0,12\end{array}$ & 0,15 & $\begin{array}{l}\text { Fulfils the } \\
\text { requirements }\end{array}$ \\
\hline & $\begin{array}{c}\text { Ceiling above the } \\
\text { unheated area }\end{array}$ & 0,53 & 0,60 & $\begin{array}{l}\text { Fulfils the } \\
\text { requirements }\end{array}$ \\
\hline
\end{tabular}

Table 3: Assessing the properties of structures to their heat transfer coefficient based on STN 730540-2/Z1 Variant Standard

\begin{tabular}{|c|c|c|c|c|}
\hline \multirow{6}{*}{ 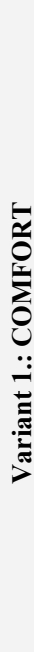 } & \multirow{2}{*}{ Structure type } & \multicolumn{2}{|c|}{$\begin{array}{c}\text { The values of the heat } \\
\text { transfer coefficients } \\
\text { UW } /\left(\mathbf{m}^{2} . \mathrm{K}\right)\end{array}$} & \multirow{2}{*}{$\begin{array}{c}\text { Results } \\
\text { according to } \\
\text { the Standard } \\
730540-2 / Z 1\end{array}$} \\
\hline & & $\begin{array}{l}\text { Designed } \\
\text { value }\end{array}$ & Target $U$ value & \\
\hline & $\begin{array}{l}\text { External wall1 } \\
\text { External wall } 2\end{array}$ & 0,15 & 0,15 & $\begin{array}{l}\text { Fulfils the } \\
\text { requirements }\end{array}$ \\
\hline & $\begin{array}{l}\text { Transparent } \\
\text { structures }\end{array}$ & 0,85 & 0,6 & $\begin{array}{c}\text { Does not fulfill } \\
\text { the } \\
\text { requirements }\end{array}$ \\
\hline & $\begin{array}{l}\text { Tent roof } \\
\text { Flat roof }\end{array}$ & $\begin{array}{l}0,09 \\
0,09\end{array}$ & 0,10 & $\begin{array}{l}\text { Fulfils the } \\
\text { requirements }\end{array}$ \\
\hline & $\begin{array}{l}\text { Ceiling above the } \\
\text { unheated area }\end{array}$ & 0,34 & 0,35 & $\begin{array}{l}\text { Fulfils the } \\
\text { requirements }\end{array}$ \\
\hline
\end{tabular}

As it was mentioned the Variant Comfort was designed to fulfil the Target heat transfer coefficient values, except the windows and doors. The
Table 3: Assessing the properties of structures to their heat transfer coefficient based on STN 730540-2/Z1 Variant Standard

\begin{tabular}{|c|c|c|c|c|}
\hline \multirow{6}{*}{ 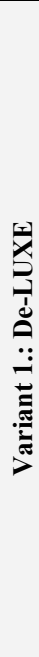 } & Structure tyne & \multicolumn{2}{|c|}{$\begin{array}{c}\text { The values of the heat } \\
\text { transfer coefficients } \\
\text { UW } /\left(\mathbf{m}^{2} . \mathbf{K}\right)\end{array}$} & \multirow{2}{*}{$\begin{array}{c}\text { Results } \\
\text { according to } \\
\text { the Standard } \\
730540-2 / \mathrm{Z1}\end{array}$} \\
\hline & & $\begin{array}{l}\text { Designed } \\
\text { value }\end{array}$ & Target $U$ value & \\
\hline & $\begin{array}{l}\text { External wall1 } \\
\text { External wall } 2\end{array}$ & $\begin{array}{l}0,15 \\
0,14\end{array}$ & 0,15 & $\begin{array}{l}\text { Fulfils the } \\
\text { requirements }\end{array}$ \\
\hline & $\begin{array}{l}\text { Transparent } \\
\text { structures }\end{array}$ & 0,55 & 0,6 & $\begin{array}{l}\text { Fulfils the } \\
\text { requirements }\end{array}$ \\
\hline & $\begin{array}{l}\text { Tent roof } \\
\text { Flat roof }\end{array}$ & $\begin{array}{l}0,09 \\
0,09\end{array}$ & 0,10 & $\begin{array}{l}\text { Fulfils the } \\
\text { requirements }\end{array}$ \\
\hline & $\begin{array}{l}\text { Ceiling above the } \\
\text { unheated area }\end{array}$ & 0,34 & 0,35 & $\begin{array}{l}\text { Fulfils the } \\
\text { requirements }\end{array}$ \\
\hline
\end{tabular}

Heat loss by transmission and ventilation had been calculated and compared. The results are presented in the Figure 5. For more information are heat gains and heat demand are compared of the three variants in Figure 6.

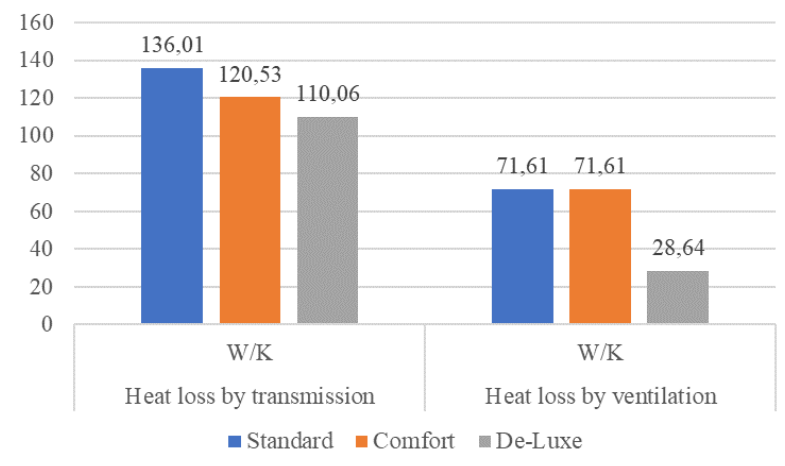

Fig. 5. Comparison of heat loss by transmission and heat loss by ventilation

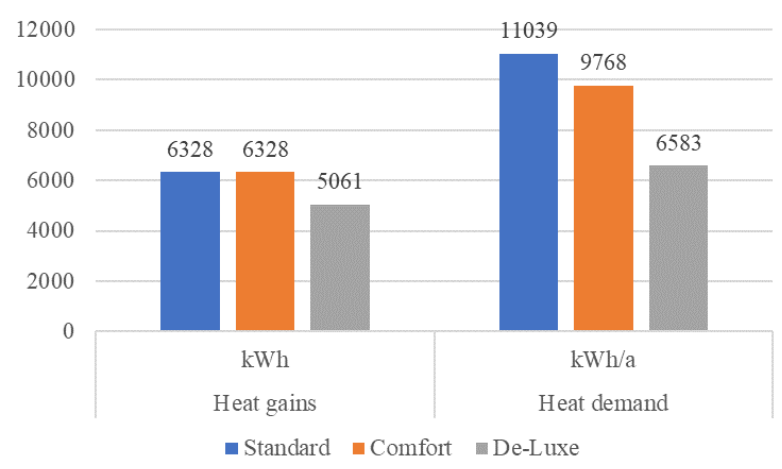

Fig. 6. Comparison of heat gains and total heat demand for the variants. 
Table 3: Classifying the calculated variants into energy classes

\begin{tabular}{|c|c|c|c|c|c|c|}
\hline & $\begin{array}{c}\text { Heating } \\
\mathrm{kWh} /\left(\mathrm{m}^{2} \cdot \mathrm{a}\right)\end{array}$ & $\begin{array}{c}\text { DHW } \\
\mathrm{kWh} /\left(\mathrm{m}^{2} \cdot \mathrm{a}\right)\end{array}$ & $\begin{array}{c}\text { Mechanical } \\
\text { ventilation and } \\
\text { cooling } \\
\mathrm{kWh} /\left(\mathrm{m}^{2} . \mathrm{a}\right) \\
\end{array}$ & $\begin{array}{c}\text { Total energy } \\
\text { need }\end{array}$ & $\begin{array}{c}\text { Primary } \\
\text { energy need } \\
\mathrm{kWh} /\left(\mathrm{m}^{2} \cdot \mathrm{a}\right)\end{array}$ & $\begin{array}{c}\text { Emissions of } \\
\text { CO2 } \\
\mathrm{kg} /\left(\mathrm{m}^{2} \cdot \mathrm{a}\right) \\
\end{array}$ \\
\hline \multirow{2}{*}{ STANDARD } & 67,38 & 16,11 & - & 83,49 & 91,84 & 18,37 \\
\hline & $\mathrm{B}$ & $\mathrm{B}$ & NOT CLASSIFIED & B & A1 & - \\
\hline \multirow{2}{*}{ COMFORT } & 59,62 & 16,11 & 0,11 & 75,84 & 73,02 & 14,57 \\
\hline & B & B & NOT CLASSIFIED & $\mathrm{B}$ & A1 & - \\
\hline \multirow{2}{*}{ DE-LUXE } & 16,98 & 7,41 & 4,9 & 37,99 & 32,54 & 2,47 \\
\hline & $\mathbf{A}$ & $\mathbf{A}$ & NOT CLASSIFIED & A & A0 & - \\
\hline
\end{tabular}

\section{Discussion}

In this project three variants were defined for the same single-family house to compare their energy consumption. The main indicator of the energy balance is primary energy need. For the variant $1-$ Standard this number was $92 \mathrm{kWh} /(\mathrm{m} 2 . \mathrm{a})$, for the second variant it was $73 \mathrm{kWh} /(\mathrm{m} 2 . \mathrm{a})$ and for the third one $32 \mathrm{kWh} /(\mathrm{m} 2 . \mathrm{a})$.

To summarize the energy consumption calculations, we can easily declare that the third variant (De-Luxe) is the best choice from total energy consumption point of view, with $38 \mathrm{kWh} /(\mathrm{m} 2 . \mathrm{a})$. We should not to forget the investments to achieve this low number. Installation of the very expensive thermal insulation materials and the environmental technology very based on renewable energy sources. In the future total investments for the whole reconstruction will be calculated for all the variants and compare to each other.

\section{Conclusion}

Energy efficiency is the utilization of less energy to provide the same service. Increasing energy efficiency not only allows individuals and organizations to reduce their capital and operational costs, is can also help lower fuel consumption and so reduce the emission of greenhouse gases and help prevent climate change.

Current policies and investments in building energy efficiency are not on track to achieve the targets. Nearly two-thirds of countries still do not have any building energy codes in place. This article showed the options to get an ultra-low energy building (variants standard and comfort) or nearly zero energy building (variant de-luxe) from a 50 years old building with application of modern thermal protection and modern environmental technology.

\section{Acknowledgement}

This work was supported by the Ministry of Education, Science, Research and Sport under VEGA Grants $1 / 0807 / 17$ and $1 / 0847 / 18$. Also need to say thank you to company VELUX, Klára Bukolská and Mr. and Mrs. Dorsic.

\section{References}

1. Jurelionis A., Seduikyte L. (2010) Assessment of indoor climate conditions in multifamily buildings in Lithuania before and after renovation. 2nd International conference advanced construction. Kaunas, Lithuania.

2. M. Economidou, B. Atanasiu, C. Despret, M. Economidou, J. Maio, I. Nolte, O. Rapf, et al. BPIE. Buildings Performance Institute Europe: Europe's building under the microscope. A country by country review of the energy perfomance of buildings. Brussels: Building Perfomance Institute Europe (BPIE). 2011. ISBN: 9789491143014.www.environment.gov.au

3. G. Dall'O', A.Galante, G.Pasetti. A methodology for evaluating the potential energy savings of retrofitting residential building stocks. Sustainable Cities and Society, Vol. 4, 2012, pp. $12-21$. ISSN: 2210-6707.

4. CA-EPBD, Implementing the Energy Performance of Building Directive- featuring country reports 2010.Brussels, April 2011ISO EN 7730:2005 Ergonomics of the thermal environment

5. J. Kmet'ková, M. Krajčík. Energy efficient retrofit and life cycle assessment of an apartment building. 6th International Building Physics Conference, IBPC 2015. Energy Procedia. Vol. 78, 2015, pp. $3186-3191$.

6. J. Kmet'ková, M. Krajčík. Cost optimal evaluation of energy performance requirements on apartment buildings to comply with the Energy Performance of Buildings Directive. INDOOR AIR 2014: proceedings of the 13th International Conference on Indoor Air Quality and Climate, Hong Kong, China, 7.-12.7.2014. Vol. 1, Pokfulam: The University of Hong Kong, 2014, pp.432-439. ISBN 9789628513864.

7. STN $730540-2 / \mathrm{Z1}$

8. Law no. $555 / 2005,364 / 2012$

9. Directive no. $300 / 2012$

10. Krajčík, Petráš Energetické hodnotenie budov 2015, ISBN 978-80-227-4462-1 